RESEARCH PAPER

\title{
Mathematical modeling of two-dimensional unconfined flow in aquifers
}

\author{
R. V. WAGHMARE* AND S.B. KIWNE \\ Department of Mathematics, Deogiri College, AURANGABAD (M.S.) INDIA (Email: sbkiwne@ yahoo.co.in)
}

\begin{abstract}
Derivation of general equation for two-dimensional aquifer flow is given. In this derivation we perform a volume balance instead of a mass balance and obtained analytical solutions of two-dimensional saturated flow under various condition. We also constructed transient unconfined groundwater flow equation by combining continuity equation with the Darcy law and provide an analytical solution.
\end{abstract}

Key Words : Aquifer, Analytical solution, Unconfined, Two-dimensional, Transmissivity, Isotropic

View point paper : Waghmare, R.V. and Kiwne, S.B. (2017). Mathematical modeling of two-dimensional unconfined flow in aquifers. Asian Sci., 12 (1\&2): 1-10, DOI : 10.15740/HAS/AS/12.1and2/1-10.

\section{* Author for correspondence}

R. V. Waghmare, Department of Mathematics, Shivaji Arts, Commerce and Science College, Kannad, AURANGABAD (M.S.) INDIA (Email: waghmarerv@yahoo.com) 